\title{
Immunogenicity and Keeping Quality Studies of Inactivated Rift Valley Fever Oil Vaccines
}

\author{
Diana M.A. Ezzaldeen, Atwa M. H*, Mona A. El-Manzalawy, Taradi A. S1, Hassan K.E.Z, \\ Marwa Y. H \\ Veterinary Serum and Vaccine Research Institute, Abbasia, Cairo, Egypt
}

*Corresponding Author: Atwa M. H, Veterinary Serum and Vaccine Research Institute, Abbasia, Cairo, Egypt.

\begin{abstract}
This work aims to improve and enhance the immunogenicity of the locally produced inactivated $R V F$ vaccine to induce high level of elongated duration of immunity in vaccinated animals using Montanide oils adjuvant (ISA 206 and ISA 50). Validity and keeping quality for all forms of the prepared vaccines were evaluated by measuring the $E D_{50} \mathrm{ml}$ at different intervals of preservation at $4^{\circ} \mathrm{C}$. Twenty susceptible sheep were used in this study divided into four groups(five sheep/group) vaccinated with Aluminum Hydroxide gel inactivated RVF vaccine (group-1), Montanide Oil ISA 206 inactivated RVF vaccine (group-2), Montanide Oil ISA 50 inactivated RVF vaccine (group-3) and unvaccinated control group (group-4).The humeral immunity in vaccinated sheep was evaluated using serum neutralization test (SNT) and enzyme linked immunosorbant assay (ELISA) where the protective immune response was detected in group (2) by serum neutralization test at $2^{\text {nd }}$ week post vaccination while in group (3) it was detected at the $1^{\text {st }}$ month post vaccination with values of $1.8 \log 10$ and $2.8 \log 10$ respectively and stayed within protective till the end of 10 months in Group 2 and $14^{\text {th }}$ months in Group 3 with values of $1.7 \log 10$ and $\left.1.7 \log 10\right)$ respectively. These results was correlated to that obtained by ELISA indicating that Montanide Oil ISA 50 is the preferable oil adjuvant to the inactivated RVF vaccine inducing the highest and longest protective immune levels in vaccinated animals.
\end{abstract}

Keywords: RVF, SNT, ELISA, MONTANIDE OIL , ISA 206, ISA 50

\section{INTRODUCTION}

RVF is a viral zoonosis that primarily affects domestic animals (including cattle, sheep, camels and goats) and to a lesser extent human. The RVF virus is highly contagious for humans when handling potentially-infected livestock. Raising awareness of the risk factors of RVF transmission as well as protective measures such as vector control and protection against mosquito bites in addition to vaccination, are the key to reduce human infection and deaths (WHO, 2019).

The progress in vaccine production is directed towards the selection of the proper adjuvant that can elaborate high and long standing immunity. Adjuvants are considered as one of the important factors in vaccine formulations that increase the immune response either humeral and cell mediated immunity (Dalsgarrd et al., 1990).

RVFV circulation in most African countries and certain Middle Eastern countries has been documented by serological surveys, animal and human cases and outbreak reports (Clements et al., 2016 and Redding et al., 2017). Since 2000, epizootic events associated with human cases have been reported in Saudi Arabia and Yemen (2000-2001), Egypt (2003), Kenya, Tanzania, Somalia and Sudan (2006-2007); Madagascar (2008-2009), South Africa and Namibia (2009-2011); Mauritania (2010, 20122015); Senegal (2013-2014); Uganda and Niger (2016); Kenya (2018), South Sudan (2018) (WHO 2018, Nyakarahuka et al., 2019 and WHO 2019) and in South Africa; (OIE 2018) reported human RVF cases associated with an isolated outbreak on a sheep farm in the Free State Province of South Africa at the end of the 2017-2018 in the mosquito season and last recorded RVF cases were in Sudan 2019 with 47 infected cases including 2 deaths (WHO 2019).

Vaccine adjuvant is a very important factor which stimulates specific components of either humeral or cell-mediated immune response (Lombard et al., 2007). Selecting the ideal or the most suitable adjuvant is one of the 
important tools in improving the efficacy of the RFV vaccine. An ideal adjuvant is one which can stimulate the humeral immune response early, and promote production of high antibody titers that would last long. It should also stimulate the cellular immune response (Daoud et al., 2013 and Ibrahim 2011). The oil adjuvant has the capability for generating a rapid, high and long-lasting immune response. Generally, the Montanide series of oil adjuvants (SEPPIC, France) has a clear immunological effect for inactivated vaccine in different susceptible animals (Dara et al., 2013 and Patil et al., 2002).

The present study evaluates in a comparison the efficacy of different oil based adjuvants used in RVF vaccine formulation in addition to Aluminum Hydroxide gel to select the best adjuvant which could be able to induce high long duration of immunity in vaccinated sheep.

\section{MATERIALS AND METHODS}

\subsection{Experimental Animals}

\subsubsection{Suckling Mice}

Ten of three to five days old baby Swiss Albino mice were used test the safety of the prepared inactivated RVF vaccines.

\subsubsection{Weand mice}

Swiss Albino weaned mice of 21-30 days old were used for evaluating the validity of the prepared vaccines. All mice were supplied by the Lab Animal Breeding Unit, Veterinary Serum and Vaccine Research Institute (VSVRI), Abbasia, Cairo, Egypt.

\subsubsection{Sheep}

Twenty local breed sheep of 3-4 months old were used for evaluation of their immune response to the prepared vaccines. All of these animals were screened using serum neutralization test (SNT) and proved to be free from RVF antibodies. They were housed under strict hygienic measures in insect proof stables receiving balanced ration and adequate water. Also these animals were examined and proved to be apparently healthy and free from external and internal parasites.

\subsection{Tissue Culture Cells}

Baby Hamster Kidney cells (BHK21) were obtained from VSVRI, Abbasia, and maintained in Eagls minimum essential medium with 8$10 \%$ bovine serum as described by Xuan et al., (2011), and were used for virus propagation, vaccine production and SNT.

ARC Journal of Animal and Veterinary Sciences

\subsection{Virus}

The original Rift Valley Fever (RVF) virus was that isolated from a human patient in Zagazig, Sharkia Province and supplied by NUMRU -3 . It was designated as ZH501 with a titer of $10^{7.5}$ $\mathrm{TCID}_{50} / \mathrm{ml}$ and used in vaccine preparations and serological tests.

\subsection{Samples}

Serum samples were collected from sheep before vaccination and after vaccination until the end of the experiment. Sera were stored at $20^{\circ} \mathrm{C}$ and inactivated at $56{ }^{\circ} \mathrm{C}$ for 30 minutes before being used in the serological studies (SNT and ELISA).

\subsection{Adjuvants}

\subsubsection{Aluminium Hydroxide Gel}

It was obtained from (Alliance Bio Company, USA), Lot. No. 11-274-30 and used in concentration of $20 \%$ as adjuvant for RVF inactivated vaccine preparation.

\subsubsection{Montanide ISA Oils}

Montanide oils ISA 206 and ISA 50 were supplied by Seppic, Paris, France) resembling a group of oil/ surfactant based adjuvants were used for preparation of experimental inactivated RVF vaccines.

\subsection{Vaccine Preparation}

The used procedure of vaccine preparation included the following steps:

\subsubsection{Propagation of the Vaccinal Virus}

Confluent BHK cell sheets in Roux flasks were inoculated with the RVF virus and incubated at $37^{\circ} \mathrm{C}$ and examined daily for cytopathic effect (CPE) which usually occurred after $48-72$ hours. The flasks were subjected twice to freezing and thawing and then the harvest was aseptically mixed together and centrifuged for 10 minutes at $3000 \mathrm{rpm}$ in a cooling centrifuge. The supernatant fluids constituted the required virus for vaccine preparation. This virus was tested for its sterility as well as titrated in tissue culture and in 3-4 weeks old adult mice.

\subsubsection{Virus Inactivation}

RVF virus was inactivated with Binary (2Bromoethyle ammonium bromide with sodium hydroxide) according to Blackburn and Besselaar (1991) as follow:

RVF virus grown in BHK monolayer culture having a titer of $10^{7.5} \mathrm{TCID}_{50} / \mathrm{ml}$ in tissue 
culture was mixed with $1 \%$ of $0.1 \mathrm{M} \mathrm{BEI}$ in 0.2 $\mathrm{N} \mathrm{NaOH}$ solution to give a final concentration of $0.001 \mathrm{M}$ of BEI. The virus and BEI mixture was mixed well and placed in a water bath at $37^{\circ} \mathrm{C}$ till complete inactivation then $2 \%$ sodium thiosulphate solution was added to neutralize the residual BEI and stopping its over action.

\subsubsection{Safety Test in Mice}

The safety test of the prepared inactivated virus was performed by intracerebral (I/C) inoculation of 10 suckling mice $(3-5$ days old) each with $0.03 \mathrm{ml}$ of inactivated virus and subjected to daily observation for 10 days for any signs of RVF disease or deaths according to El-Nimr (1980) and Eman (1995).

\subsubsection{Vaccine Formulation}

Three formula of inactivated RVF vaccine were prepared as follow:

Formula-1: using 20\% Aluminium hydroxide gel $20 \%$ as adjuvant

Formula-2: using Montanide oil ISA 206 as adjuvant

Formula-3: using Montaniode oil ISA 50 as adjuvant

\subsubsection{Evaluation of the Prepared Vaccine Formulae}

\subsubsection{Sterility Test}

The freedom of the prepared inactivated RVF vaccines from foreign contaminants (Mycoplasma, aerobic, and anaerobic bacteria, and fungi) was tested at the Rift Valley Fever Department, VSVRI, Abbasia, Cairo.

\subsubsection{Potency Test}

Fivefold dilutions of each vaccine formula were prepared in suitable media starting from 1:1 to $1: 625$. Five groups of weaned mice (21-28 days old) were used for each dilution and each mouse was inoculated with two doses 0.2 mlof the vaccine $\mathrm{I} / \mathrm{P}$, one week a part. Seven days after the second inoculation, all animals were challenged via intraperitoneal (I/P) route with $0.1 \mathrm{ml}$ of RVF virus containing $10^{3}$ MIPLD50 / $\mathrm{ml}$ this was in addition to other two groups of mice, one group inoculated with challenge virus as positive control and the other group was kept as non vaccinated non challenged negative control. All groups of mice were kept under observation for 21 days and deaths were recorded daily. The $\mathrm{ED}_{\mathbf{5 0}} / \mathrm{ml}$ was calculated according to the method of Reed and Muench (1938). Deaths occurred during the first day were considered non specific.
2.6.6. Determination of the Validity of the Oil Vaccines

Vaccine validity was determined by estimating the $\mathrm{ED}_{50}$ of the two oil vaccines at $4^{\circ}$ and $25^{\circ} \mathrm{C}$ (room temperature) by applying potency test at different periods in comparison with the Aluminium hydroxide inactivated RVF vaccine (The permissible limit of $\mathrm{ED}_{50}$ is 0.02 as reported by Randall et al., 1962 and Gihan et al., 1998).

\subsection{Scheme of Sheep Vaccination}

Each sheep group included 5 animals managed as follow:

Group-1: Each sheep was inoculated S/C with $1 \mathrm{ml}$ of inactivated aluminum hydroxide gel adjuvanted RVF vaccine.

Group-2: Inoculated $\mathrm{S} / \mathrm{C}$ with $1 \mathrm{ml} /$ animal of ISA 206 oil adjuvanted inactivated RVF vaccine.

Group-3: Inoculated $\mathrm{S} / \mathrm{C}$ with $1 \mathrm{ml} /$ animal of ISA 50 oil adjuvanted inactivated RVF vaccine.

Group-4: was kept as non vaccinated (control negative).

\subsection{Sampling}

Serum samples were obtained from all sheep before and after vaccination at intervals of 7,14 , 21 days and then monthly for 15 months post vaccination and kept at $-20^{\circ} \mathrm{C}$ until used for serological assays.

\subsection{Evaluation of the Humoral Immune Response}

Collected serum samples from vaccinated and non vaccinated sheep were tested for the presence of antibody against RVF virus by SNT using the technique calculated the antibody titer as described by Reed and Muench (1938) and indirect ELISA according to Voller (1976).

\subsection{Statistical Analysis}

The obtained data were statistically analyzed by (SPSS system, version16) to estimate mean \pm standard error (SE) and ANOVA for the effects of treatment and time on parameters under investigation SPSS 2007: statistical analysis: version 16.

\section{RESULTS AND DISCUSSION}

This study was carried out to evaluate the immunogenicity and duration of immunity in sheep vaccinated with different preparations inactivated RVF vaccine with different 
montanide oil adjuvants in comparison with the aluminum hydroxide gel inactivated vaccine.

Through the present work it was found that all prepared inactivated RVF vaccine formulae were free from foreign contaminants (aerobic and anaerobic bacteria; fungi and mycoplasma) as tested by the Rift Valley Fever Department and safe inducing no mortalities or any signs of illness (no allergic reaction, no inflammation, no granuloma, no swelling, no sterile abscess or fever) were observed on inoculated suckling mice during 10 days of observation period.
Regarding the use of oils as adjuvants to the inactivated RVF vaccine; viscosity of such oils is considered as an important factor during selection of a suitable adjuvant, as the high viscosity can results in undesirable side effect as postvaccinal reaction. Table (1) demonstrates the viscosity of the use Monatinde oil adjuvants used in this study as stated by manufacture (Seppic, Paris) at $25^{\circ} \mathrm{C}$ as $30 \mathrm{mPa} . \mathrm{s}$ for the montanide ISA206 and $200 \mathrm{mPa} . \mathrm{s}$ for Montanide ISA 50 as it was concluded that the use of oils as vaccine adjuvants should be of low viscosity as stated Bomford (1997).

Table1. Montanide oil viscosity

\begin{tabular}{|c|c|c|}
\hline Vaccine Component & Vaccine 1 & Vaccine 2 \\
\hline Antigen & \multicolumn{2}{|c|}{ Rift valley fever virus ZH501 } \\
\hline Adjuvant (montanide) & ISA 206 & ISA 50 \\
\hline Type of emulsion & Water-in-oil-in-water & Water-in-oil \\
\hline Oil viscosity at $25^{\circ} \mathrm{c}$ & 30 & 00 \\
\hline
\end{tabular}

Table (2) showed that all prepared inactivated agreement with what reported by Randall et al $\mathrm{RVF}$ vaccines had an acceptable $\mathrm{ED}_{50} / \mathrm{ML}$ (1962) and Gihan et al (1998).

(Permissible limit: not more than $0.02 / \mathrm{ml}$ ) in

Table2. $E D_{50} / M L$ of the prepared inactivated $R V F$ vaccines in mice

\begin{tabular}{|c|c|}
\hline Type of vaccine & ED50/ML \\
\hline Aluminium hydroxide gel inactivated RVF vaccine & 0.0017 \\
\hline Montanide oil (ISA 206) inactivated RVF vaccine & 0.0013 \\
\hline Montanide oil (ISA 50) inactivated RVF vaccine & 0.0010 \\
\hline
\end{tabular}

Clinical examination of vaccinated sheep including body temperature for 7 days post vaccination, showed no clinical signs except 2 sheep in the group vaccinated with montanide oil ISA 50 which showed post vaccinal reaction

Table3. Body temperature of vaccinated sheep in different groups

\begin{tabular}{|c|c|c|c|c|c|c|c|c|}
\hline \multirow{3}{*}{ Animal Group } & \multicolumn{8}{|c|}{ Mean Temperature n Degree } \\
\hline & \multirow{2}{*}{$\begin{array}{c}\text { Before } \\
\text { Vaccination }\end{array}$} & \multicolumn{7}{|c|}{ Days Post Vaccination } \\
\hline & & $1^{\mathrm{st}}$ & $2^{\text {nd }}$ & $3^{\text {rd }}$ & $4^{\text {th }}$ & $5^{\text {th }}$ & $6^{\text {th }}$ & $7^{\text {th }}$ \\
\hline $\begin{array}{l}\text { G(1) vaccinated with Aluminium hydroxide gel } \\
\text { ionactivated RVF vaccine }\end{array}$ & 39.4 & 39.5 & 39.4 & 39 & 38.7 & 39.4 & 39.4 & 38.9 \\
\hline $\begin{array}{l}\text { G(2) vaccinated with Montanide oil ISA } 201 \text { inactivated } \\
\text { RVF vaccine }\end{array}$ & 39.5 & 39.3 & 39.5 & 38.9 & 39.1 & 39.4 & 39.4 & 38.9 \\
\hline $\begin{array}{l}\text { G(3) vaccinated with Montanide oil ISA } 50 \text { inactivated } \\
\text { RVF vaccine }\end{array}$ & 39.4 & 39.2 & 38.8 & 38.9 & 39 & 39.5 & 39.6 & 39.4 \\
\hline G(4) control non vaccinated & 39.4 & 39.6 & 39.7 & 39.3 & 39.5 & 39.6 & 39.5 & 39.6 \\
\hline
\end{tabular}

Evaluation of the humoral immune response in sheep vaccinated with different preparations of inactivated RVF vaccine through application of SNT and ELIZA on their serum samples revealed the tabulated results in tables $(4 \& 5)$ and fig (1\&2). It was noticed that the results obtained by ELIZA came in parallel to that obtained by SNT. The SNT and ELIZA antibody titer against RVFV were negative along the whole experiment in the non vaccinated control sheep. Serum neutralization index in vaccinated sheep with Monatinde ISA 206 began to increase from 0.18 before at the site of injection with no elevation of body temperature as shown in table (3) confirmed the safety of the prepared vaccines in agreement with the recommendations of Marwa (2015). vaccination to reach its protective value (1.8) by the $14^{\text {th }}$ day post vaccination to record its peak (4.8) by the $4^{\text {th }}$ month then began to decrease to be unprotected (1.3) by the $10^{\text {th }}$ month post vaccination. Sheep vaccinated with Montanide ISA50 vaccine showed NI of 0.31 before vaccination recorded a protective level (2.8) at the $1^{\text {st }}$ month with a peak level (5.8) at the $4^{\text {th }}$ month post vaccination then began to decrease to non protective level (1.43) by the end of the $14^{\text {th }}$ month.

From tables (4) and (5) concerning the duration of the protective immunity for RVF virus, there 
was a significant difference at $\mathrm{P}<0.01$ among the different types of used oil adjuvants. The recorded higher levels of RVF antibodies in vaccinated sheep with oil adjuvants than in those vaccinated with aluminum hydroxide gel vaccine could be attributed to the fact that oil adjuvants have the capability of generating a rapid, high and long lasting immune response and the montanide oil adjuvants (SEPPIC, France) have a clear immunological effect for inactivated vaccines in different susceptible animals (Dara et al., 2013 and Patil et al., 2002),

The efficacy of Montanide adjuvant is not based on one mechanism but really on different modes of action. As emulsion have depot effect and induce a slow release of the antigen, they can recruit immune competent cells by micro diffusion of the droplets via the lymphatic system, or facilitate the antigen uptake by the antigen presenting cells, or at least playing the role of antigen presenting cells. Other mechanism such as lymphocyte trapping and modification of the cell membranes, emulsion is the result of oil phase, established with surfactant and able to modify the cell membranes or to draw together the antigen and antigen presenting cells (Aucotuier and Ganne, 2002).

These findings agree with those of Fakhry et al (2012) and Ehab et al (2015) who found that the duration of FMD immunity induced by Montanide oils ISA 206 and 50 reached 32 and 38 weeks post vaccination respectively. Also our results agree with El-Bagoury et al (2013) who reported that the duration of RVF immunity induced by Montainde oil ISA 206 reached 44 weeks post vaccination.

Table4. Mean RVF neutralizing indices of vaccinated sheep

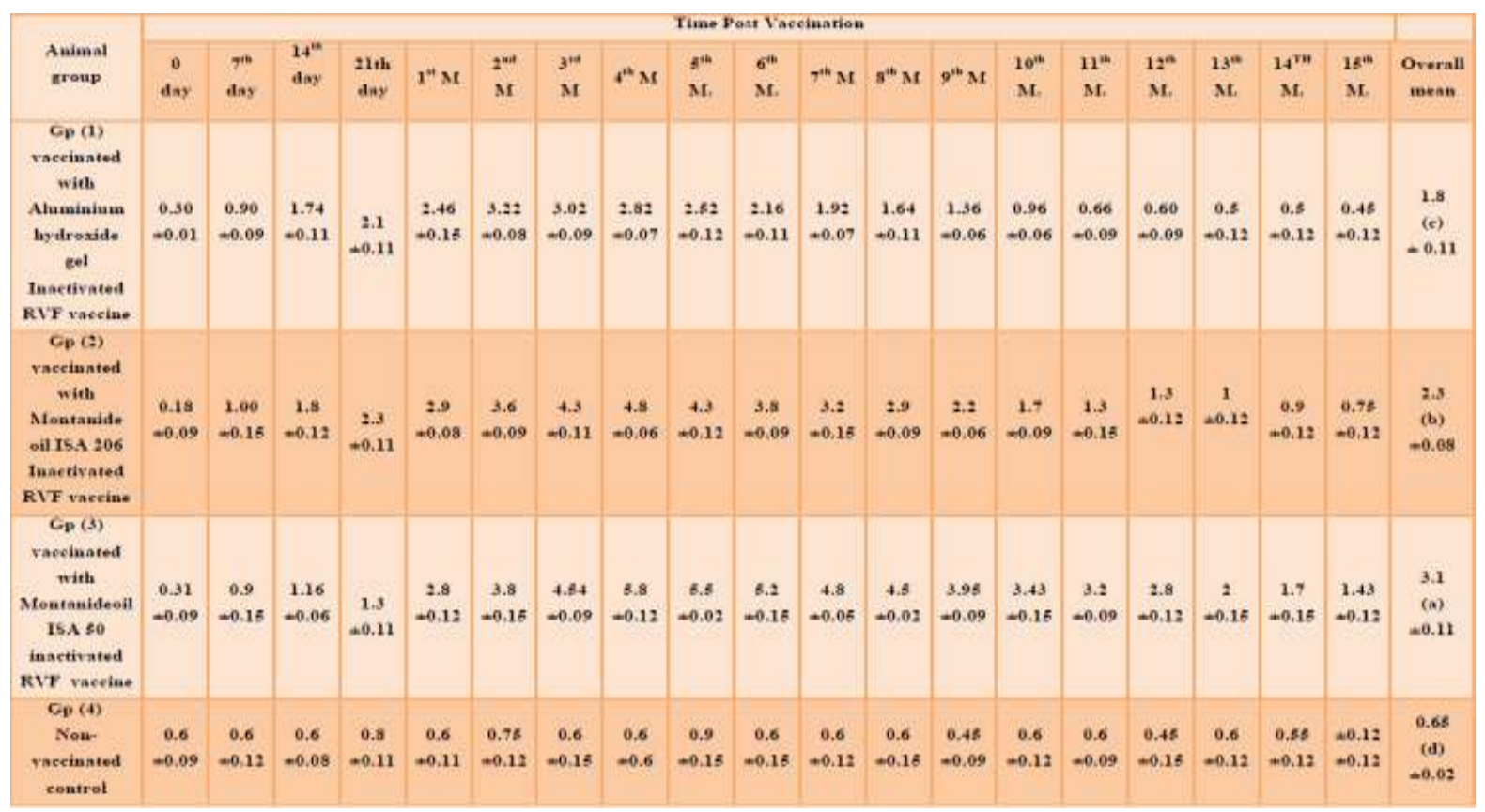

- Values with different alphabetic within the right column showed highly significant difference at $P<0.01$.

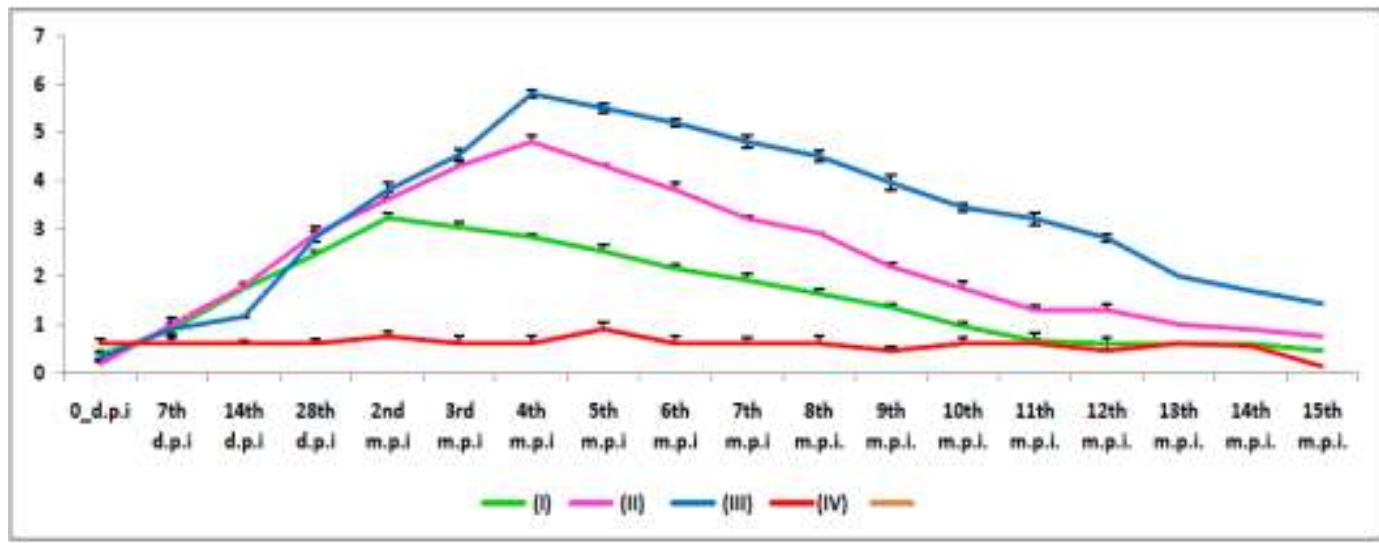

Fig1. Mean RVF neutralizing indices of sheep vaccinated with aluminum hydroxide and montanideoils inactivated $R V F$ vaccines 
Table 5.Mean values of ELISA optical density in sheep vaccinated with Aluminum hydroxide and Montanide oils inactivated $R V F$ vaccines

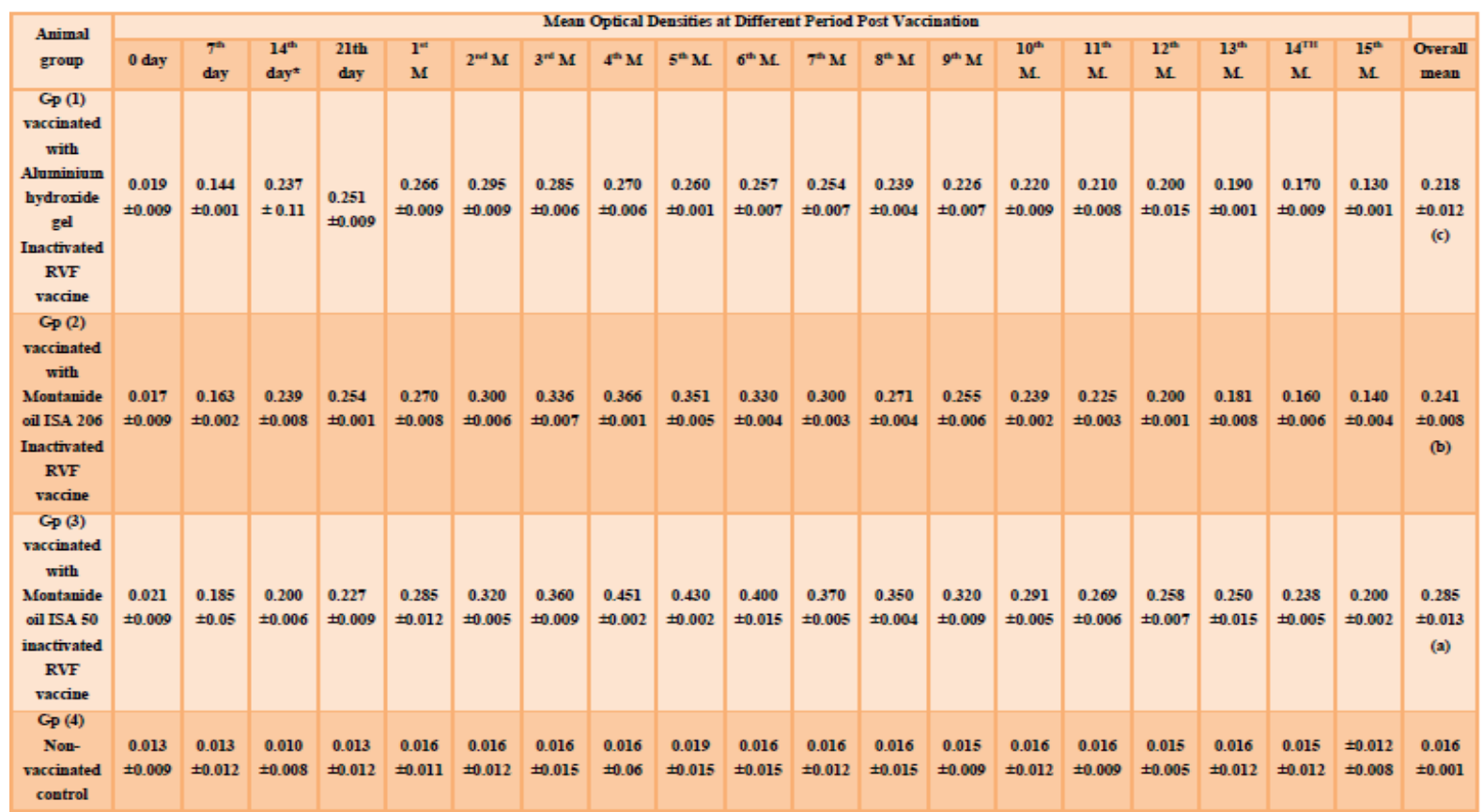

- Values with different alphabetic within the right column showed highly significant difference at $P<0.01$.

- Cut off: 0.230

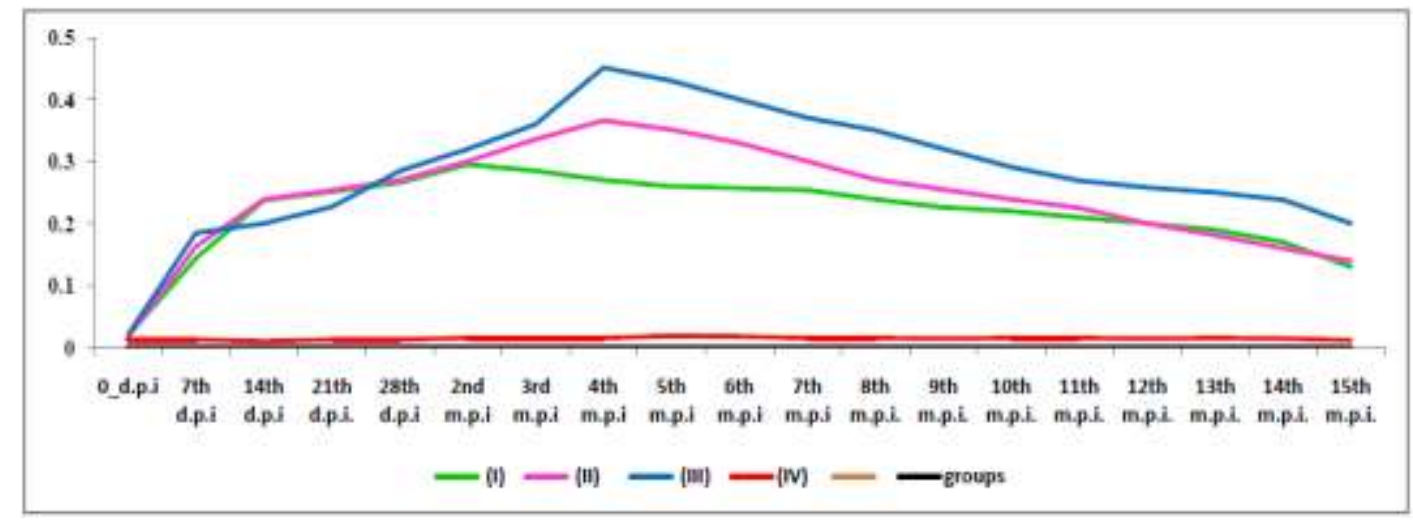

Fig2. Mean values of ELISA optical density in sheep vaccinated with Aluminium hydroxide and Montanide oils inactivated $R V F$ vaccines

On the other side evaluation of validity of the prepared inactivated RVF vaccine formulae kept at $4^{\circ}$ and $25^{\circ} \mathrm{C}$; table (6) showed that by estimating the effective dose fifty (ED50/ml), all forms of RVF oil vaccines were valid within the permissible limit $\left(0.02 \mathrm{ED}_{50} / \mathrm{ML}\right)$ up to 12 months except aluminium hydroxide gel which still valid up to 9-10 months only in agreement with the results recorded by Randall et al., (1962) and Gihan et al., (1998). Table (7) showed that the ISA 206 oil vaccine kept its potency at $25^{\circ} \mathrm{C}$ for at least 4 weeks while the ISA 50 oil vaccine stayed within the permissible limit till the $5^{\text {th }}$ week.

So it could be concluded that $4^{\circ} \mathrm{c}$ is the best temperature for storage of the oil inactivated RVF vaccines as they were valid for one year, but under recommended temperature $25^{\circ} \mathrm{c}$ they stayed valid for weeks in agreement with Samira et al. (1999) and Ehab et al.(2015).

Table6. Validity of different preparations of $R V F$ vaccine at $4{ }^{\circ} \mathrm{C}$

\begin{tabular}{|c|c|c|c|c|c|c|c|c|c|c|}
\hline \multirow{2}{*}{ Type of Vaccine } & \multicolumn{8}{|c|}{ Time Post Vaccination } \\
\cline { 2 - 11 } & Zero day & $2^{\text {nd }} \mathrm{m}$ & $4^{\text {th }} \mathrm{m}$ & $6^{\text {th }} \mathrm{m}$ & $7^{\text {th }} \mathrm{m}$ & $8^{\text {th }} \mathrm{m}$ & $9^{\text {th }} \mathrm{m}$ & $10^{\text {th }} \mathrm{m}$ & $11^{\text {th }} \mathrm{m}$ & $12^{\text {th }} \mathrm{m}$ \\
\hline $\begin{array}{c}\text { Aluminium hydroxide } \\
\text { Inactivated RVF vaccine }\end{array}$ & 0.0017 & 0.0017 & 0.0040 & 0.0068 & 0.0097 & 0.0147 & 0.0203 & 0.0248 & 0.0300 & 0.0320 \\
\hline Montanide ISA 206 oil & 0.0012 & 0.0012 & 0.0011 & 0.0010 & 0.0009 & 0.007 & 0.008 & 0.006 & 0.007 & 0.009 \\
\hline
\end{tabular}




\begin{tabular}{|c|c|c|c|c|c|c|c|c|c|c|}
\hline Inactivated RVF Vaccine & & & & & & & & & & \\
\hline $\begin{array}{c}\text { Montanide ISA 50 oil } \\
\text { Inactivated RVF Vaccine }\end{array}$ & 0.0009 & 0.0008 & 0.0007 & 0.0004 & 0.0005 & 0.0004 & 0.005 & 0.004 & 0.006 & 0.007 \\
\hline
\end{tabular}

Table 7.Validity of different preparations of $R V F$ vaccine at (room temperature) $25^{\circ} \mathrm{C}$

\begin{tabular}{|c|c|c|c|c|c|c|c|c|}
\hline \multirow{2}{*}{ Type of Vaccine } & \multicolumn{7}{|c|}{$\mathbf{6}^{\text {th }}$} & $\begin{array}{c}\mathbf{7}^{\text {th }} \\
\mathbf{W}\end{array}$ \\
\cline { 2 - 10 } & Zero day & $\mathbf{1}^{\text {st }} \mathbf{W}$ & $\mathbf{2}^{\text {nd }} \mathbf{W}$ & $\mathbf{3}^{\text {rd }} \mathbf{W}$ & $\mathbf{4}^{\text {th }} \mathbf{W}$ & $\mathbf{5}^{\text {th }} \mathbf{W}$ & $\mathbf{W}$ \\
\hline $\begin{array}{c}\text { Aluminium hydroxide } \\
\text { Inactivated RV F vaccine }\end{array}$ & 0.0017 & 0.0020 & 0.0200 & 0.0292 & 0.0302 & 0.0485 & 0.070 & 0.107 \\
\hline $\begin{array}{c}\text { Montanide ISA 206 oil } \\
\text { Inactivated RVF Vaccine }\end{array}$ & 0.0012 & 0.0158 & 0.0196 & 0.020 & 0.026 & 0.045 & 0.070 & 0.099 \\
\hline $\begin{array}{c}\text { Montanide ISA 50 oil } \\
\text { Inactivated RVF Vaccine }\end{array}$ & 0.0009 & 0.0112 & 0.0144 & 0.0190 & 0.0220 & 0.0280 & 0.055 & 0.075 \\
\hline
\end{tabular}

\section{CONCLUSION}

All the present obtained results gave the priority to the prepared inactivated montanide oil ISA 206 and ISA 50 RVF inactivated vaccines over the local inactivated aluminum hydroxide gel adjuvanted RVF vaccine.

Montanide oils (206 and 50) RVF vaccines induce long lasting immunity ranged between 10 and 14 months post vaccination. Further, studies are recommended to evaluate the effect of these Montanide oils on the cellular immune response

\section{REFERENCES}

[1] Aucotuier J, Ganne V., (2002): Adjuvants designed for vet use. Seppic incorporation limited company.

[2] Blackburn n, K. and Besselaar T,G. (1991): A STUDY OF the effect of chemical inactivates on the epitopes of Rift Valley Fever virus glycoproteins using monoclonal antibodies. J.Virol. Methods 1991 Aug; 33(3): 367-74.

[3] Bomford, R. (1997): Adjuvants in veterinary vaccines In: Mowat, N., Rweyemamu, M., editors. Vaccine Manual: The Production and Quality Control of Veterinary Vaccines for Use in Developing Countries. FAO, Rome. p277-284.

[4] Clements A, C., Pfeiffer D, U. and Martin,V. (2016): Application of knowledgedriven spatial modelling approaches and uncertainty management to a study of Rift Valley fever in Africa. Int. J. Health Geogr. 2006 Dec 10; 5:57

[5] Dalsgarrd, K.; Hilgus, L. andTroune, C. (1990):Classical and new approaches to adjuvant use in domestic food animals. Adv. Vet. Sci. Comp. Med., 35:121-159.

[6] Daoud, H.M., Ibrahim, E.E., El-Din, W,M.G., and Hassanin, A.I.H. (2013) Preparation of foot and mouth disease trivalent vaccine type A, O, SAT2 and determination of the Guinea pig protective dose 50 (GPPD50). Vet. World, 6(11): 844-851.

[7] Dara, P., Kalaivanana, R., Sied, N., Mamo, B., Kishore, S,Suryanaraya, V.V. and Kondabattula, G. (2013):MontanideISATM 201 adjuvanted FMD vaccine induces improvedimmuneresponses and protection in cattle. Vaccine J.,31: 3327-3332.

[8] Ehab El-Sayed Ibrahim, Wael Mossad Gamal, Amr Ismail Hassan, Safy El-Din Mahdy, Akram Zakria Hegazy And Magdy Mahmoud Abdel-Atty (2015): Comparative study on the immunopotentiator effect of ISA 201, ISA 61,ISA 50, ISA 206 used in trivalent foot and mouth disease vaccine. Veterinary World 8(10): 1189-1198.

[9] Elbagoury, G. F., El-Habbaa, A. S., Ibrahim, A. M. and Noha, E.E. Yousef (2013): Evaluation of Inactivated Rift Valley Fever Vaccine with Paraffin oil adjuvant. Benha Veterinary Medical Journal, Vol.25, No. 1:157-164.

[10] El-Nimr, M.M. (1980): Studies on the inactivated vaccine against Rift Valley Fever, Ph. D. Thesis (Microbiology) Fac. Vet. Med. Assuit Univ. Egypt.

[11] Eman. M. S. S. (1995): Studies on RVF vaccine inactivated with Binary, $\mathrm{Ph}$. D. Sc. thesis Microbiology, Fac. of Vet. Med. Cairo Univ.

[12] Fakhry, H. M., Rizk, S. A., Abu- Elnaga, H.I., Deghaidy, W. Talaat, A. A. and Hegazi, A. Z. (2012): Field application of bivalent foot and mouth disease vaccine adjuvanted with Montanide ISA $(25,50,206)$ and IMS (1113-3015) as an alternative to aluminum hydroxide gel. Egypt. J. Virol., 9(1): 123-136.

[13] Gihan, K. M.; Elian, K. A. and Eman, M. S. (1998): Studies on the keeping quality of binary inactivated Rift Valley fever Vaccine, Assuit Vet. J., 39, (77): 169 - 179. 
[14] Ibrahim, E.E. (2011): Advanced studies on Foot and Mouth Disease Vaccines of sheep in Egypt, Ph. D.Sc. Thesis (Infectious Diseases), Faculty of Veterinary Medicine, Cairo University, Egypt.

[15] Lombard, M., Pastoret, P.P. and Moulin, A.M. (2007): A brief of vaccines and vaccination. Rev. Sci. Tech., 26(1): 29-48.

[16] Marwa, Y. Hammad (2015): Some Studies on Rift Valley Fever Vaccine. PhD. Benha University.

[17] Nyakarahuka I, Balinandi S, Mulei S, KyondoJ, Tumusiime A, and Klena J, (2019): Ten outbreaks of rift valley fever in Uganda 2016-2018: epidemiological and laboratory findings, Int. J. Infect Dis. 2019; 79:4

[18] OIE (2018):Rift Valley Fever, South Africa. Information received from Dr. Bothle Michael Modisane, Chief Director, Department of Agriculture, Forestry and Fisheries, Animal Production and Health, Pretoria, South Africa $16 / 5 / 2018$

[19] Patil, P.K., Boyry, J., Ramoi Krishna, C., Hugar, B.,Misrol, L.D. And Natarajan, C. (2002): Immune response ofgoats against FMD quadrivalent vaccine: Comparison ofdouble oil emulsion and aluminum hydroxide gel vaccinein eliciting immunity. Vaccine, 20: 2671-2789.

[20] Randall, R.; Gibbs, C. J.; Aulisio, C. G.; Binn, L. N. and Harrison, V. R. (1962): The development of a formalin-killed Rift Valley fever virus vaccine for use in $\operatorname{man}_{2}$ J.Immunol.; 89:660-71.
[21] Redding DW, Tiedt s, Lo iacono G, Bett B, and Jones KE.(2017): Spatial, seasonal and climatic predictive models of Rift Valley fever disease across Africa. Philos Trans R SocLond B Biol Sci. 2017 Jul 19;372(1725).

[22] Reed, L. J. and Muench, H. (1938): A simple method for estimating 50percent end point. Am. J. Hyg., 27: 493-497.

[23] Samira El-Kilany, El- Watany, H., Abd ElRahman, A.O., Fadia Fahmy, (1999): The effect of long term storage at $4^{\circ} \mathrm{C}$ on the stability of FMD vaccine formulated with different adjuvants. Alexandria Journal of Veterinary Sciences 15 (1), 35-42

[24] Voller, A.; Bidwell, D. and Bartlett, A. (1976): Microplateenzymeimmunoassay for the immune diagnosis of virus infection.Am. Soc. for Micro. 506-512

[25] World health Organization: Rift Valley Fever - Kenya - Disease Outbreak News [Internet]. Geneva: WHO; (2018) [cited 27 February 2019]. Available from: http://www.who.int/csr/don/18-june-2018-riftvalley-feverkenya

[26] World Health Organization: RIFT Valley Fever [INTERNET]. Geneva: WHO; (2019): [cited 26 February 2019]. Available from: http://www.who.int/news-room/factsheets/detail/rift-valley-fever

[27] Xuan, H., Li, Y., Fang, H. and Zheng, C. (2011): Establishment of persistent infection with foot and mouth disease virus in BHK21 cells. Virol. J., 8: 169.

Citation: Diana M.A. Ezzaldeen, Atwa M. H, Mona A. El-Manzalawy, Taradi A. S1, Hassan K.E.Z, Marwa Y. H. Immunogenicity and Keeping Quality Studies of Inactivated Rift Valley Fever Oil Vaccines. ARC Journal of Animal and Veterinary Sciences. 2020; 6(1):11-18. doi:dx.doi.org/ 10.20431/2455-2518.0601002.

Copyright: (C) 2020 Authors. This is an open-access article distributed under the terms of the Creative Commons Attribution License, which permits unrestricted use, distribution, and reproduction in any medium, provided the original author and source are credited. 